\title{
THE CONTROL OF LAND USE AND UTILIZATION IN KUPANG REGENCY THROUGH THE LAW FORMATION ${ }^{\Omega}$
}

\author{
Wini Dina Retriani Lani \\ Postgraduate Program Universitas Nusa Cendana \\ E-mail:wini.lani@yahoo.com
}

\begin{abstract}
Demand for land in Kupang Regency keeps increasing while the land availability is limited and the changes in the utilization continues. If it is not controlled, there will be a gap between econo-mic orientation and the environmental sustainability. However, the control does not work due to the absence of legal instruments such as Regional Regulation which regulates this issue. To answer these legal issues, the researchers applied empirical juridical research methods while the analysis method is prescriptive juridical. The research shows that the control of land use and utilization in Kupang Regency is not effectively implemented because Regional Regulation of Detailed Spatial Plan of Regency and Spatial Plan of Strategic Area, the utilization license and the change of land use license have not been formulated. Moreover, an integrated license process is not effectively applied which caused several constructions are built prior to the license granted, unclear boundary between forest and non-forest area, incomplete data base of agriculture, farm, and absentee land.
\end{abstract}

Keywords: control, land use, land utilization

\begin{abstract}
Abstrak
Kebutuhan akan tanah di Kabupaten Kupang semakin meningkat namun ketersediaannya terba-tas serta perubahan penggunaan dan pemanfaatan tanah terus berlangsung. Apabila tidak dikendali-kan menimbulkan kesenjangan antara orientasi ekonomi dan kelestarian lingkungan. Pengendalian ini tidak terlaksana karena tidak adanya instrument hukum berupa Peraturan Daerah yang mengatur hal tersebut.Untuk menjawab persoalan hukum ini peneliti menggunakan metode penelitian yuridis empiris. Metode analisis yang digunakan adalah yuridis preskriptif. Hasil penelitian membuktikan bahwa pengendalian penggunaan dan pemanfaatan tanah di Kabupaten Kupang tidak optimal karena belum dibentuknya Peraturan Daerah tentang Rencana Detail Tata Ruang Kabupaten dan Rencana Tata Ruang Kawasan Strategis, Izin pemanfaatan dan izin perubahan penggunaan tanah. Selain itu perizinan satu pintu tidak optimal pelaksanaannya sehingga terdapat pembangunan sebelum disetujuinya izin terkait, belum ada batas yang jelas antara kawasan hutan dan di luar kawasan hutan, belum lengkapnya data base pertanian, peternakan, dan tanah absentee.
\end{abstract}

Kata kunci: pengendalian, penggunaan tanah, pemanfaatan tanah

\section{Introduction}

Kupang Regency as one of the regencies in Nusa Tenggara Timur Province continues developing. The capital was formerly located in the center of Kupang City has now moved to Oelamasi eastward development progress. The displacement of this capital has caused the changes on the use and utilization of land in various sectors of public life.

The different perception and comprehension in the land use and utilization might raise a conflict of interest in relation to the space utili- zation. It can sparks the dualism of interests between economic orientation and environmental sustainability. The utilization of land shall be adapted to the land use in order to conform to the land capability and environmental carrying capacity. ${ }^{1}$

$\Omega \quad$ This article is derived from Research Thesis 2016 entitled Pengendalian Penggunaan dan Pemanfaatan Tanah Di Kabupaten Kupang Ditinjau dari Peraturan Pemerintah No 16 Tahun 2004 tentang Penatagunaan Tanah

1 Ruslan Wirosoedarmo, et.al, "Rencana Tata Ruang Wilayah (RTRW) Berdasarkan Daya Dukung Lingkungan Berbasis Kemampuan Lahan", Jurnal Agritech, Vol. 34 No. 
The term of space utilization patterns relates to the spatial distribution aspects of resource utilization activity fund while the utilizeation of space control consists of licensing mechanism and the implementation of development in order to remain in accordance with the Spatial Area Plan that has been planned. ${ }^{2}$ The establishment of legal instrument has not been formed to control the use and utilization of land. Similarly, its changes cause suboptimal institutional arrangements associated with the utilization of land. It is important for the law development to regulate them as well as the use and utilization of land in the area especially Kupang Regency to fit in the spatial allotment.

Hence, it is necessary to form regional laws to meet the legal demand related to the use and utilization of land in Kupang Regency as well as relevant Regional Regulations to accommodate the land use as a subsystem of Spatial Area for social welfare.

\section{Problems}

The problems formulated in this article are whether the control the land use and utilization in Kupang Regency is already compliance with the allotment and whether the efforts to control the land use and utilization for the of regional law formation is in accordance with its allotment?

\section{Research Methods}

This is an empirical juridical research which was conducted in Kupang Regency of East Nusa Tenggara Province. The informants of this research involve Civil State Apparatus (ASN) in the Regional Development and Planning Agency of Kupang Regency, Land Office of Kupang, Land Services Agency of Kupang, and the Member of the Regional House of Representatives of Kupang.

4, November 2014, Malang: Faculty of Agricultural Technology Universitas Brawijaya, page 472.

Wahyu Hidayat, Ernan Rustiadi and Hariadi Kartodihardjo, "Dampak Pertambangan Terhadap Perubahan Penggunaan Lahan dan Kesesuaian Peruntukan Ruang (Studi Kasus Kabupaten Luwu Timur Provinsi Sulawesi Selatan)", Jurnal Perencanaan Wilayah dan Kota. Vol. 26 No. 2, Agustus 2015, Bogor: Master of Science Planning Region Program IPB, page 134.
Methods of Data collection was done by interviews, field observation, and study the legal documentation. Data Processing Method was applied by editing, data classification, data tabulation, and data verification. Analysis of the data used deductive qualitative method towards the substance material of the existing law and the legal establishment in the area as the controller in the use and utilization of land. Analysis of the substance material of the legislation was guided by the principles and rules of law, as well as the conception or theory of law which is relevant to the issues in this research.

\section{Discussion}

The Land Use and Utilization in Kupang Regency

Kupang Regency is the second largest area after East Sumba regency i.e. 11.156\% of the total area of the province of NTT. The high population density is concentrated in Central Kupang Regency, Amarasi Regency, Sulamu, West Kupang, East Kupang and Taebenu i.e. population density above 100 inhabitants per squa-re kilometer which is nearer to the Kupang City. The total area and population density relates to the use and utilization of land in that area. The lowest population density is in the West Fatuleu Regency with an average of 18 inhabitants per square kilometer of its area.

The use in relation to the utilization of land in Kupang Regency cannot be separated from the function of spatial planning and land policy which is regulated by Government and the Regional House of Representatives including the Regional Development and Planning Agency (BAPPEDA) of Kupang, The Land Office (Kantah) of Kupang, Land Services Agency (DPP) of Kupang and the Regional House of Representatives (DPRD) Kupang.

Data from the National Land Agency Regional Office of East Nusa Tenggara Province in Land Use Balance of Kupang Regency for 2012 showed that the use of land cultivated by population is dominated by upland area of 233.824 . $317 \mathrm{M}^{2}$, or $4.23 \%$, fields covering $67.370 .781 \mathrm{M}^{2}$ or $1.22 \%$, mixed farms covering $114.196 .188 \mathrm{M}^{2}$, or $2.07 \%$. And shifting cultivation area of 
14.475.581 $\mathrm{M}^{2}$ or $0.26 \%$. While the rest are nonagricultural cultivation area designated for residential area covering $57.775 .745 \mathrm{M} 2$ or $1.05 \%$. These data indicate that the use of land in Kupang Regency has not been effectively implemented in which the highest percentage i.e. shrubs $31.21 \%$, although it might be a change of use and utilization on that percentage since the given scale is $1: 25.000$ so the interpretation is inaccurate where small areas of the use and utilization of land are not visible. This is in line with the research of Fauzi Iskandar, et al (2016) which states that the processing suitability of land should be done with reference to the unit of land in order to obtain accurate plot area of higher conformity ${ }^{3}$.

The empirical facts related to the land use in Kupang are provided below: first, there is land utilization that is not in accordance with the given license; for example the public fuel stations (SPBU) construction in Timor Raya Noelbaki street, the change of land use was allowed for about $2.000 \mathrm{~m}^{2}$ but it applies on approximately $10.000 \mathrm{~m}^{2}$. People keep doing a development and changes of the use and utilization of land although it is not allowed and there is no firm action yet from the government as a controller considering this activity has been done since 2012.

Second, there is location license to various deginations. During 2010 - 2014 there were 17 locations aimed to land service department (dpp) Kupang. There are some licenses that had already processed and some cannot due to incomplete stuff and under coordination phase. This indicates that there are constructions and alteration of the use and utilization of land formerly was vacant land and then it is used either agriculture or non-farming. Location license is permission given to the company to acquire land required to capital investment that also pervailed as license to transfer of rights, and

Fauzi Iskandar, et.al, "Kesesuaian Penggunaan Lahan Terhadap Rencana Tata Ruang/Wilayah di Kecamatan Kutoarjo Menggunakan Sistem Informasi Geografi", Jurnal Geodesi, Vol. 5 No. 1, January 2016, Semarang: Faculty of Engineering Universitas Diponegoro, page 7. for using the land for trade investment purposes.

Third, regional regulation on the use and utilization of land changes license is not present resulting in the sanctions absence if a violation of the land use occurs. So far the land office will provide approval of technical consideration when the use and ulitization of land has an advice plan of BAPPEDA in terms that a local government determine to agree or disagree about changing of the use and utilization of land. One of the problems is no detail of spatial plan so it takes times to give advice plan regarding the plot of field must be done directly to look at the real condition in the field. After that it is adapted to Regional Spatial Plan that is still very common. It is less effective and time consuming while fees are charged to the applicant. The research in the land Kupang regency office shows that the sub district gives a significant change particularly in East Kupang and Central Kupang sub districts. The uncontrolled changes occurred continuously will affect the sustainability of farmland. The agricultural land divided into the smaller sectors also makes changing to the use and utilization of land and the certificates are often done to sell the land transferred into yard.

Fourth, the problem of the use and utilization of land such as people occupation in Cultivation Rights Title on neglected land in Kuimasi village. It occurred because there is no complete data base in the areas of agriculture, husbandry, forestry that appropriated with spatial and there are no empty lands data collection. ${ }^{4}$ This is in line with the results of the BPN mapping that the highest presentage of the use and utilization of land in Kupang regency is unused bushes.

The Formation of Law as Land Use and Utilization control in Kupang regency

Government authority in the land use and utilization is regulated by government regula-

\footnotetext{
Interviews with Head of Regional Representatives of Kupang Period 2014-2019 Yosef Lede, 7 December 2015 in Oelamasi Kupang.
} 
tion number 16 of 2004 on the administration land namely the general plan on supplies, designation, and the use of water and natural resources. The administration land has the elements: a series of activities which includes field data collection related to the utilization, mastery and the ability the physical land; the making of plan/pattern land use for the benefit of development and supervision and integration in its implementation; land use has to be wellplanned by the eternal, optimal, compatible and balanced principles, purposes to achieve maximum social welfare to be equitable and prosperous society. ${ }^{5}$

Regional government has authority to regulate space usage referring to the regional Kupang regency regulation number 1 Year 2015 on regional spatial plan. Hence information designation space (advice plan) should refer to detail spatial plan.

Government Accommodation to information designation space is only implemented on special sectors related to community demand that requires license related to the use and utiliization of space including inside the soil. Controlling usage of space has not implemented effectively because the plan detail and zoning regulation should be the basis for/control reference usage of space has not been made/has not been arranged in the regional regulation.

The general plan about supplies, designation, and use of the earth, water and natural resources in the Regional Spatial Plans (RTRW) Kupang regency is not exclusively made. Regional Spatial Plans set the function space over the land and the sea in a general in pattern space plan and the spatial structure plan. Indirectly Regional Spatial Plans also set about which treatment to do in the cultivation and conservatory area also any treatment that allowed conditional that carried out on protected areas and cultivation areas. ${ }^{6}$

Kupang Regional Government since 2010 established Regional Land Service Department

5 Samun Ismaya, 2013, Hukum Administrasi Pertanahan, Yogyakarta: Graha IImu, page 2-3.

6 Interviews with Coordinating Head of Area Plan and Development Cooperation BAPPEDA Kupang Regency on November $26^{\text {th }} 2015$ in Oelamasi Kupang. whose main duties and functions are structuring, regulating the use and utilization of land including governing the use and utilization of land in Kupang and one of that functions is providing the location license in coordination with relevant institutions. Land that can be designated as location license is a land according to the spatial plan is allocated for investment. ${ }^{7} \mathrm{Be}$ sides location license, the DPP also provides recommendations about Utilization of Land Use for area under one hectare, but there's no regional regulation governing Land Utilization License and Changes Land Use License. To manage the use and utilization of land, DPP has also carried out Inventory Mastery, Ownership, Utilization and Land Use (IP4T) even though only in some villages. ${ }^{8}$

Land Office is an extension of the duties and authority of the Ministry of Agricultural and Spatial Planning/National Land Agency (BPN) of Republic Indonesia at the district/city level that have a strategic role in the utilization of space including land. Briefly, main role of BPN in the utilization of space is realizing the presence of the State in land policy as people's living space. Policy that related with the use and utilization of land is carrying out the making of the Balance Sheet The stewardship of Land but its implementation in the regional level has not been maximized, and the other land services related to the use and utilization of land is there are services Technical Considerations of Land in order to Location License, Location Determination and Change Land Use License.

Furthermore, concerning the regulations and policy on the use and utilization of land from the views and opinions of the representatives in the House of Representatives (DPRD) Kupang that Regional Regulation particularly on the use and utilization of land is not already yet. Regarding to this, the Government has not submitted the form of regional regulation about

\footnotetext{
7 Hery Listyawati, "Kegagalan Pengendalian Alih Fungsi Tanah Dalam Perpektif Penatagunaan Tanah Di Indone sia”, Jurnal Mimbar Hukum, Vol. 22 No. 1, 2010, Yogyakarta: Faculty of Law Universitas Gadjah Mada, page 47.

8 Interview with Head of Evaluation and Land Guidance DPP Kupang Regency, on November $18^{\text {th }}, 2015$ in Oelamasi Kupang.
} 
the use and utilization of land. However, Regional Legislation Programme (Prolegda) 2016 the House Representative (DPRD) would discuss the initiative regional regulation about land containing the land authority in the area for allocation and utilization of land and regional policy regarding with Regional Spatial Plans has not been maximal implemented thoroughly. ${ }^{9}$

Regional regulations and policy on the use and utilization in Kupang has not been specifically regulated but it is seen that each institutions has a legal instrument to control the use and utilization of land yet in the scope and each sectoral interest which causes no conformity in terms of requirements and implementation. As a result, the people who will use and take advantages of the land did not know exactly which rules should be followed or used. This is why the use and utilization of land is not in accordance with the general plan that has been set.

The land use according to Government Regulation (PP) Number 16 Year 2004 held in stages through determining adjustment mastery, the use and utilization of land that carried out by the government, institutions that classified of land accordance time period Regional Spatial Plans, in scope Regional Government Kupang Regency has not been carried out, but had been conducted by BPN in fiscal year 2012 and until now there's no refurbished and the implementations in the regions not maximal because the less of socialization and coordination with regional Government.

The requirements for using and utilizing land manifested in Land Use Technical Guidelines land that become a part of settlement land administration include right displacements, right increase, merger and separation, and field division which has been implemented in Kupang Regency by Land Office of Kupang Regency. The agricultural lands which would be diverted is obliged to qualified the requirements that has been set. Similarly it applies to increase or change of rights, separation of field.

Interview Result with Head of House Representative (DPRD) Kupang Regency 2014-2019 period, Vice of Head I, Head of Commission on December $7^{\text {th }} 2015$ in Oelamasi Kupang.
The implementation of land Use on Government Regulation Number 16 Year 2004 in Kupang Regency includes: first, inventory of control, ownership, the use and utilization of land (IP4T). This activity had been conducted by Kupang Regency Land Office in 2014 at East Baumata Village, Taebenu Subdistrict as many as 600 fields and in 2015 at Bipolo Village, Sulamu subdistrict as many as 500 fields and in the previous years which was then followed up with certification for community land. ${ }^{10}$ Kupang Regency Land Service Department had also been conducted IP4T in Sulamu subdistrict on 2015 and in East Kupang subdistrict, exactly in Oesao Village and Naibonat. Despite its implementation, it only applied to partial areas since these activities take time, effort and considerable expense. Inventory began with field surveys, aggregation of physical data and aggregation of juridical data, measurement, mapping and report the inventory result. These activities was conducted per field for it involved ownership. Second, ratio determination between availability and control, use and utilization of land according to areas function through Balance Sheet of land Use. The balance sheet has been done by referring to the Regional Spatial Plans of 1993. Consequently, it is not relevant to today condition, especially for densily populated and developing areas. Third, adjustment pattern determination of the use and utilization with Regional Spatial Plans. Having the availability and control obtained, the use and utilization of land according to areas function, then the adjustment pattern of the use and utilization of land with Regional Spatial Plans is determined. So far it was conducted by using Regional Spatial Plans which is general, as a result, the use and utilization of land specifically is not reached.

Based on the research, it was found that the use and utilization of land in Kupang district is not optimal for several reasons; Local Regulation on the Regional Regulation of Detailed Spatial Plan (RDRT) and Spatial Planning Strategic

\footnotetext{
10 Interview result with Head of Land Office Kupang Regency, on December, $3^{\text {th }} 2015$ in Oelamasi Kupang.
} 
Area (RTR), license of the use of land, there is no license for the change of use of land, ineffectively implemented license of one door, existing construction before the approval of the licenserelated permissions, there is no clear boundary between forest areas and outside forest areas, incomplete data base of agriculture, husbandry, uncultivated vacant land, and land absentee.

Land is a spatial physical aspects thus land use is one manifestation of the spatial utilization. Hierarchically, the general plan (RTRW) is followed by detailed spatial plan containing the use of land that can be aligned with land usage. ${ }^{11}$ It is important to formulate Local Regulations on detailed spatial plan and other license to accommodate arrangement the use and utilization of land. This is in line with the results of research Suwitno Y. Imran in different areas that the function of the spatial arrangement in preserving the environment get various problems that inter-sector and inter-regional, environmental degradation due to irregularities spatial, both on land, sea and air, and support for the development of the region is not optimally implemented indicated by the lack of sector policy support towards the development of national strategic areas and regions. The commitment of the Government is required to address these issues one of which is regulations or local regulations. ${ }^{12}$ Sumardji in Santoso $(2013)^{13}$ described authority as the rule of law (reschtsmacht) related to the right to control in which the government has the power to use the land according to the needs and purposes. Government regulate the use and utilization of land by the existing regulations although it is not optimal.

Government in legal liability as a controller in the use and utilization of land necessarily

11 AM Yunus Wahid, 2014, Pengantar Hukum Tata Ruang, Jakarta: Kencana, page 206.

12 Suwitno Y. Imran, "Fungsi Tata Ruang dalam Menjaga Kelestarian Lingkungan Hidup Kota Gorontalo", Jurnal Dinamika Hukum, Vol.13 No.3, September 2013, Purwokerto: Faculty of Law Universitas Jenderal Soedirman, page 458 .

13 Urip Santoso, "Kewenangan Pemerintah Daerah dalam Penguasaan Atas Tanah", Jurnal Dinamika Hukum, Vol. 13 No. 1, January 2013, Purwokerto: Faculty of Law Universitas Jenderal Soedirman, page 103-104. form a concrete law. Supports the establishment of regional autonomy in the area of law that is more in line with condition and character of each area. According Rahayu, ${ }^{14}$ surveillance systems as the implications of the authority of central and local government according to the Local Government Act 2014 is not quite right because it tends to weaken the autonomy and toward recentralisation. This is contrary to the essence of regional autonomy that should emphasize the portion of the local government to take care of all the needs of the region in accordance with the specific conditions of the area. Therefore, local governments should be given discretion in taking care of the area for the welfare of the local people.

Control of the use of space is in the form of licensing in accordance with existing authority of local government in the city and regency level..$^{15}$ Control of the use and utilization of land is a preventive and accommodative measure to realize the use and utilization of land for their designated purpose and can create safe, comfortable, productive and sustainable a space. Hence, potential and given resources provide maximum benefit for the Indonesian prosperity, especially in Kupang Regency.

\section{Conclusion}

The ineffective Control of the use and utilization of land in Kupang Regency is caused by the Provincial Regulation on Detailed Spatial Plan and the District Spatial Plan Strategic Area. The condition was also supported by the ineffectively implemented one door license, broad geographical conditions resulting in the too large mapping causing different interpretation. On the other hand land requirement increase is not followed by availability, even some constructions existed before the approval of the li-

\footnotetext{
14 Derita Prapti Rahayu, "Pengawasan Preventif Sebagai Kontrol Pusat Terhadap Daerah Di Era Reformasi", Padjajaran Jurnal Ilmu Hukum, Vol. 2 No. 3, 2015, Bandung: Faculty of Law Universitas Padjadjaran, page 461.

15 Anis Widyawati, "Implementasi Perda No.13 Tahun 2004 tentang Rencana Detail tata Ruang Kota (RDTRK), Kotamadya Daerah Tingkat II Kotamadya Semarang BWK III (Kecamatan Gunung Pati)", Jurnal Dinamika Hukum, Vol. 13 No. 1, January 2013, Purwokerto: Faculty of Law Universitas Jenderal Soedirman, page 43.
} 
cense - related permissions. Moreover, there is no clear boundary between forest areas and outside forest areas, incomplete data base of agriculture, husbandry, uncultivated vacant land, and absentee land.

\section{Suggestion}

Efforts to control the use and utilization of land by the formation of local laws to comply with the designation shall be implemented by forming Provincial Regulation on detailed spatial plan, strategic regional spatial planning, land use license and license of land use changes, forming the control of the use and utilization of land, forest area with the Spatial paduserasi and streamline the civil service investigators Spatial field.

\section{References}

Hidayat, Wahyu. Ernan Rustiadi and Hariadi Kartodihardjo. "Dampak Pertambangan Terhadap Perubahan Penggunaan Lahan dan Kesesuaian Peruntukan Ruang (Studi Kasus Kabupaten Luwu Timur Provinsi Sulawesi Selatan)". Jurnal Perencanaan Wilayah dan Kota. Vol. 26 No. 2. Agustus 2015. Bogor: Master of Science Planning Region Program IPB;

Imran, Suwitno Y. "Fungsi Tata Ruang dalam Menjaga Kelestarian Lingkungan Hidup Kota Gorontalo". Jurnal Dinamika Hukum. Vol. 13 No. 3. September 2013. Purwokerto: Faculty of Law Universitas Jenderal Soedirman;

Iskandar, Fauzi. Et.al. "Kesesuaian Penggunaan Lahan Terhadap Rencana Tata Ruang/ Wilayah di Kecamatan Kutoarjo Mengguna- kan Sistem Informasi Geografi". Jurnal Geodesi. Vol. 5 No. 1. January 2016. Semarang: Faculty of Engineering Universitas Diponegoro;

Ismaya, Samun. 2013. Hukum Administrasi Pertanahan. Yogyakarta: Graha Ilmu;

Listyawati, Hery. "Kegagalan Pengendalian Alih Fungsi Tanah Dalam Perpektif Penatagunaan Tanah Di Indonesia". Jurnal Mimbar Hukum. Vol. 22 No. 1. 2010. Yogyakarta: Faculty of Law Universitas Gadjah Mada;

Rahayu, Derita Prapti. "Pengawasan Preventif Sebagai Kontrol Pusat Terhadap Daerah Di Era Reformasi". Padjajaran Jurnal Ilmu Hukum. Vol. 2 No. 3. 2015. Bandung: Faculty of Law Universitas Padjadjaran;

Santoso, Urip. "Kewenangan Pemerintah Daerah dalam Penguasaan Atas Tanah". Jurnal Dinamika Hukum. Vol. 13 No. 1. January 2013. Purwokerto: Faculty of Law Universitas Jenderal Soedirman;

Wahid, AM Yunus. 2014. Pengantar Hukum Tata Ruang. Jakarta: Kencana;

Widyawati, Anis. "Implementasi Perda No.13 Tahun 2004 tentang Rencana Detail tata Ruang Kota (RDTRK). Kotamadya Daerah Tingkat II Kotamadya Semarang BWK III (Kecamatan Gunung Pati)". Jurnal Dinamika Hukum. Vol. 13 No. 1. January 2013. Purwokerto: Faculty of Law Universitas Jenderal Soedirman;

Wirosoedarmo, Ruslan. et.all. "Rencana Tata Ruang Wilayah (RTRW) Berdasarkan Daya Dukung Lingkungan Berbasis Kemampuan Lahan". Jurnal Agritech. Vol. 34 No. 4. November 2014. Malang: Faculty of Agricultural Technology Universitas Brawijaya. 